\title{
Peningkatan Hasil Belajar Menulis Surat Undangan Menggunakan Model Think Talk Write (TTW) dengan Penguatan Karakter Demokratis pada Siswa Kelas V SDN Kepanjenkidul 1 Kota Blitar
}

\author{
Diyah Anggita Wijaya*, Sutansi, Lilik Bintartik \\ Universitas Negeri Malang, Jl. Semarang No. 5 Malang, Jawa Timur, Indonesia \\ *Penulis korespondensi, Surel: diyahanggia@gmail.com
}

Paper received: 2-2-2021; revised: 20-2-2021; accepted: 27-2-2021

\begin{abstract}
This study aims to describe the application of the TTW model by strengthening democratic character and describing the improvement of student learning outcomes in writing a class $\mathrm{V}$ invitation letter Kepanjenkidul 1 SDN Blitar City. The study was conducted with a qualitative approach to the type of classroom action research. In cycle I the percentage of teacher activity was 83 percent and increased in cycle II by 100 percent. The average percentage of student activity in the first cycle was 73 percent and increased in the second cycle by 92 percent. While the completeness of student learning outcomes at the pre-action stage was 42 percent. In cycle I the average completeness of student learning outcomes classically rose to 60.8 percent and increased in cycle II of 86.3 percent. Based on the above results it can be concluded that the application of the TTW model by strengthening democratic character can improve student learning outcomes in the material of writing an invitation letter.
\end{abstract}

Keywords: TTW model; writing an invitation letter; democratic character

\begin{abstract}
Abstrak
Penelitian ini bertujuan untuk mendeskripsikan penerapan model TTW dengan penguatan karakter demokratis dan mendeskripsikan peningkatan hasil belajar siswa menulis surat undangan kelas $\mathrm{V}$ SDN Kepanjenkidul 1 Kota Blitar. Penelitian dilakukan dengan pendekatan kualitatif jenis penelitian tindakan kelas. Pada siklus I persentase aktivitas guru sebesar sebesar 83 persen dan meningkat pada siklus II sebesar 100 persen. Rata-rata persentase aktivitas siswa pada siklus I sebesar 73 persen dan meningkat pada siklus II sebesar 92 persen. Sedangkan ketuntasan hasil belajar siswa pada tahap pratindakansebesar 42 persen. Pada siklus I rata-rata ketuntasan hasil belajar siswa secara klasikal naik menjadi 60,8 persen dan meningkat pada siklus II sebesar 86,3 persen. Berdasarkan hasil di atas dapat disimpulkan bahwa penerapan model TTW dengan penguatan karakter demokratis dapat meningkatkan hasil belajar siswa dalam materi menulis surat undangan.
\end{abstract}

Kata kunci: model TTW; menulis surat undangan; karakter demokratis

\section{Pendahuluan}

Menulis merupakan salah satu dari empat keterampilan berbahasa. Menurut Nurjamal dan Sumirat (2010) mengatakan bahwa menulisadalah proses kreatif menuangkan gagasan dalam bentuk bahasa tulis untuk menyampaikan tujuan, misalnya memberi tahu, meyakinkan, dan menghibur. Menulis mempunyai peranan penting dalam dunia pendidikan dan proses belajar. Menurut Susanto (2013) manfaat menulis yaitu menulis membantu menemukan kembali apa yang pernah diketahui, menulis menghasilkan ide-ide baru, membantu mengorganisasikan pikiran dan menempatkanya dalam suatu wacana yang berdiri sendiri, menulis membuat pikiran seseorang siap untuk dibaca dan evaluasi, membantu menyerap dan menguasai informasi baru, dan membantu memecahkan masalah dengan jalan memperjelas 
unsur-unsurnya dan menempatkanya dalam konteks visual sehingga dapat diuji. Keterampilan menulis tidak akan datang otomatis,membutuhkan latihan secara teratur. Seseorang yang berlatih menulis secara sitematis dan teratur akan menguasai keterampilan menulis.

Hasil observasi pembelajaran bahasa Indonesia pada kelas V SDN Kepanjenkidul 1 Kota Blitar yang dilaksanakan hari Selasa 3 Desember 2019 mengenai pelaksanaan pembelajaran muatan Bahasa Indonesia dapat dijelaskan bahwa pada awal pembelajaran guru mengucapkan salam, dilanjutkan meminta salah satu siswa memimpin berdoa kemudian presensi, kemudian melakukan apersepsi dengan tanya jawab materi yang sudah dipelajari sebelumnya. Pada kegiatan inti, guru meminta siswa membaca teks mengenai surat undangan yang ada di buku siswa. Selanjutnya guru menjelaskan mengenai materi surat undangan yang telah di baca siswa. Siswa diberi kesempatan untuk bertanya mengenai materi yang sudah di jelaskan namun semua siswa hanya diam dan tidak ada yang bertanya. Kegiatan selanjutnya siswa ditugaskan untuk membuat surat undangan pada buku tulis masing-masing, kemudian hasil pekerjaan siswa di kumpulkan untuk di nilai. Pada kegiatan akhir, guru memberikan kesempatan siswa untuk bertanya materi yang belum dipahami, kemudian guru mengahiri pembelajaran dengan mengucap salam.

Menulis merupakan salah satu alat komunikasi yang secara tidak langsung akan disampaikan kepada orang lain. Salah satu keterampilan menulis yang diajarkan di kelas V berdasarkan kurikulum 2013 adalah menulis surat undangan. Menulis surat undangan merupakan suatu keterampilan menulis yang diajarkan kepada siswa untuk menuliskan permintaan agar penerima surat datang pada suatu kegiatan yang diadakan oleh penulis. Menurut Mudiono (2010) surat merupakan suatu sarana menyampaikan informasi atau pesan dalam bentuk tulisan yang disampaikan kepada pihak lain. Berdasarkan isinya, surat dapat dibedakan atas tiga jenis. Menurut Soedjito (2018:14) yaitu (1) surat pribadi, surat yang berisi masalah pribadi ditujukan kepada keluarga, teman atau kenalan, (2) surat dinas atau resmi berisi masalah administrasi pemerintahan atau kedinasan yang ditujukan kepada suatu instansi , (3) surat niaga atau dagang, surat yang berisi masalah perniagaan atau perdagangan.

Hasil wawancara dengan guru kelas V SDN Kepanjenkidul 1 Kota Blitar bahwa Kurikulum yang digunakan di SDN Kepanjenkidul 1 Kota Blitar adalah Kurikulum 2013. Menurut penjelasan guru, pada materi surat undangan siswa kesulitan dalam menulis surat undangan. Siswa belum bisa menulis surat undangan sesuai dengan komponen menulis surat yang benar. Belum bisa membedakan surat undangan resmi dan tidak resmi, selain itu kesulitan menyusun kata menjadi kalimat. Dalam menulis surat undangan, siswa kurang memperhatikan penulisan kalimat efektif, serta masih banyak kesalahan dalam penggunaan ejaan seperti penulisan huruf kapital. Oleh karena itu hasil belajar siswa dalam menulis surat undangan masih rendah, dari 33 siswa 14 siswa mencapai nilai 75 Kriteria Ketuntasan Minimal (KKM) 25 siswa lainya mendapat nilai dibawah KKM.

Permasalahan rendahnya hasil belajar menulis surat undangan tersebut dapat diatasi dengan cara mengubah model pembelajaran yang dilakukan guru dengan model Think Talk Write (TTW). Model TTW merupakan salah satu tipe model pembelajaran Cooperative Learning. Model TTW dapat memberikan peluang kepada peserta didik untuk berinterkasi lebih banyak dengan sesama peserta didik dalam pembelajaran. Menurut Shoimin (2014). Model TTW mendorong siswa untuk berpikir, berbicara, dan menulis sehingga dapat mengembangkan pemahaman siswa terhadap sebuah konsep. 
Sebagai pelaksana pembelajaran guru harus menguasai langkah-langkah model pembelajaran TTW agar hasil belajar menulis surat undangan siswa kelas V meningkat. Langkah-langkah penerapan model pembelajaran TTW menurut Shoimin (2014), yaitu 1) Guru membagikan LKPD yang memuat soal yang harus dikerjakan oleh siswa serta petunjuk pelaksanaanya, (2) peserta didik membaca masalah yang ada dalam LKPD dan membuat catatan kecil secara individu tentang apa yang diketahui dan apa yang tidak diketahui dalam masalah tersebut menggunakan bahasanya sendiri sehingga terjadi proses berpikir (think), (3) Guru membagi siswa dalam kelompok kecil (3-5 siswa), (4) Siswa berdiskusi dengan teman satu kelompok untuk membahas isi catatan dari hasil catatan (talk) untuk menghasilkan solusi atas masalah yang diberikan, (5) Dari hasil diskusi, peserta didik secara individu merumuskan pengetahuan berupa jawaban atas soal dalam bentuk tulisan (write) dengan bahasa sendiri, (6) Perwakilan kelompok menyampaikan hasil diskusi. Sedangkan kelompok lainnya diminta memberikan tanggapan, (7) Kegiatan akhir pembelajaran adalah membuat refleksi dan kesimpulan atas materi yang dipelajari.

Pendidikan sebagai salah satu bidang kehidupan memiliki peranan penting dalam membentuk kepribadian generasi bangsa yang berkarakter di masa yang akan datang. Pendidikan karakter dianggap sebagai usaha untuk menanamkan kebiasaan-kebiasaan baik sehingga siswa bersikap dan bertindak berdasarkan nilai-nilai yang telah menjadi kepribadiannya. Pendidikan karakter adalah segala sesuatu yang dilakukan guru, yang mampu mempengaruhi karakter peserta didik. Guru membantu membentuk watak peserta didik. Hal ini meliputi keteladanan bagaimana perilaku guru, cara guru berbicara atau menyampaikan materi, bagaimana guru bertoleransi, dan berbagai hal terkait lainnya (Depdiknas ,2010). Terdapat delapan belas karakter dalam kurikulum 2013 yang harus ditanamkan kepada peserta didik di sekolah dasar. Delapan belas karakter tersebut yaitu (1) religius, (2) jujur, (3) toleransi, (4) disiplin, (5) kerja keras, (6) kreatif, (7) mandiri, (8) demokratis, (9) rasa ingin tahu, (10) semangat kebangsaan, (11) cinta tanah air, (12) menghargai prestasi, (13) bersahabat/komunikatif, (14) cinta damai, (15) gemar membaca, (16) peduli lingkungan, (17) peduli sosial, (18) tanggung jawab. Karakter merupakan serangkian sikap seperti keinginan melakukan hal yang terbaik dan komitmen dengan masyarakatnya (Andrianto dalam Haryati, 2017). Menerapkan model TTW dalam pembelajaran menulis surat undangan dapat menumbuhkan sikap toleransi daalam menerima perbedaan dan tanggung jawab terhadap apa yang menjadi kewajibanya. Dalam kegiatanya dapat membentuk karakter demokratis. Karakter demokratis dibentuk pada saat siswa diskusi dan menentukan solusi dari masalah secara bersama dan saling menerima.

Pembelajaran menulis surat menggunakan model TTW dapat menumbuhkan karakter demokratis peserta didik. Hal ini dikarenakan dalam tahap TTW terdapat fase Talk atau berbicara, peserta didik diajarkan cara berbicara, mendengarkan, memberikan tanggapan, serta memberikan kesempatan yang sama dalam kelompok saat berdiskusi. Materi surat undangan dapat diajarkan dengan baik apabila anggota kelompok saling bekerja sama, saling mendengarkan, serta saling berkomunikasi untuk memberikan kesempatan dalam menuangkan idenya. Paparan di atas diperkuat oleh pendapat Azzet (2011) bahwa untuk menumbuhkan karakter demokratis membutuhkan sikap percaya diri, kerja sama, berempati, dan berkomunikasi.

Berdasarkan pembahasan tersebut, maka diperlukan tindakan secara tepat sebagai upaya meningkatkan hasil belajar siswa dalam menulis surat undangan. Tujuan dalam 
penelitian ini yaitu mendeskripsikan peningkatan hasil belajar menulis surat undangan melalui penerapan model TTW dengan penguatan karakter demokratis pada siswa kelas V SDN Kepanjenkidul 1 Kota Blitar.

\section{Metode}

Penelitian ini dilakukan dengan menggunakan pendekatan kualitatif deskriptif yang dirancang menggunakan jenis penelitian PTK. Dilakukan melalui dua tindakan yaitu siklus I dan siklus II. Setiap siklus terdiri dari 2 pertemuan dengan 4 tahap penelitian meliputi perencanaan, pelaksanaan, pengamatan, dan refleksi. Siklus I dilaksanakan pada tanggal 29 Januari 2020 dan 30 Januari 2020, siklus II dilaksanakan pada tanggal 5 Februari 2020 dan 6 Februari 2020.

Subjek penelitian ini adalah siswa kelas V SDN Kepanjenkidul 1 Kota Blitar dengan jumlah siswa sebanyak 33 siswa terdiri dari 17 laki-laki dan 16 perempuan. Data yang digunakan dalam penelitian ini yaitu data proses dan data hasil. Data proses diperoleh dari hasil observasi aktivitas guru dan siswa. Sedangkan data hasil diperoleh dari hasil belajar siswa dalam ranah afektif (sikap), kognitif (pengetahuan), dan psikomotorik (keterampilan). Teknik pengumpulan data yang digunakan meliputi wawancara, observasi, tes,catatan lapangan, dan dokumentasi. Selanjutnya data yang telah terkumpul dianalisis melalui 3 tahap yaitu reduksi data, penyajian data, dan penarikan kesimpulan.

\section{Hasil dan Pembahasan}

Berdasarkan penelitian menggunakan model TTW pada materi menulis surat undangan pada siswa kelas V SD dengan penguatan karakter demokratis diperoleh hasil sebagai berikut. Persentase aktivitas guru pada siklus I sebesar 83\% dengan predikat baik. Pada siklus I guru belum melaksanakan tahapan think, talk secara maksimal. Usaha yang dilakukan guru untuk perbaikan siklus II dengan memberikan bimbingan dan pengawasan lebih detail kepada siswa sehingga meningkat pada siklus II sebesar $100 \%$ dengan predikat sangat baik.

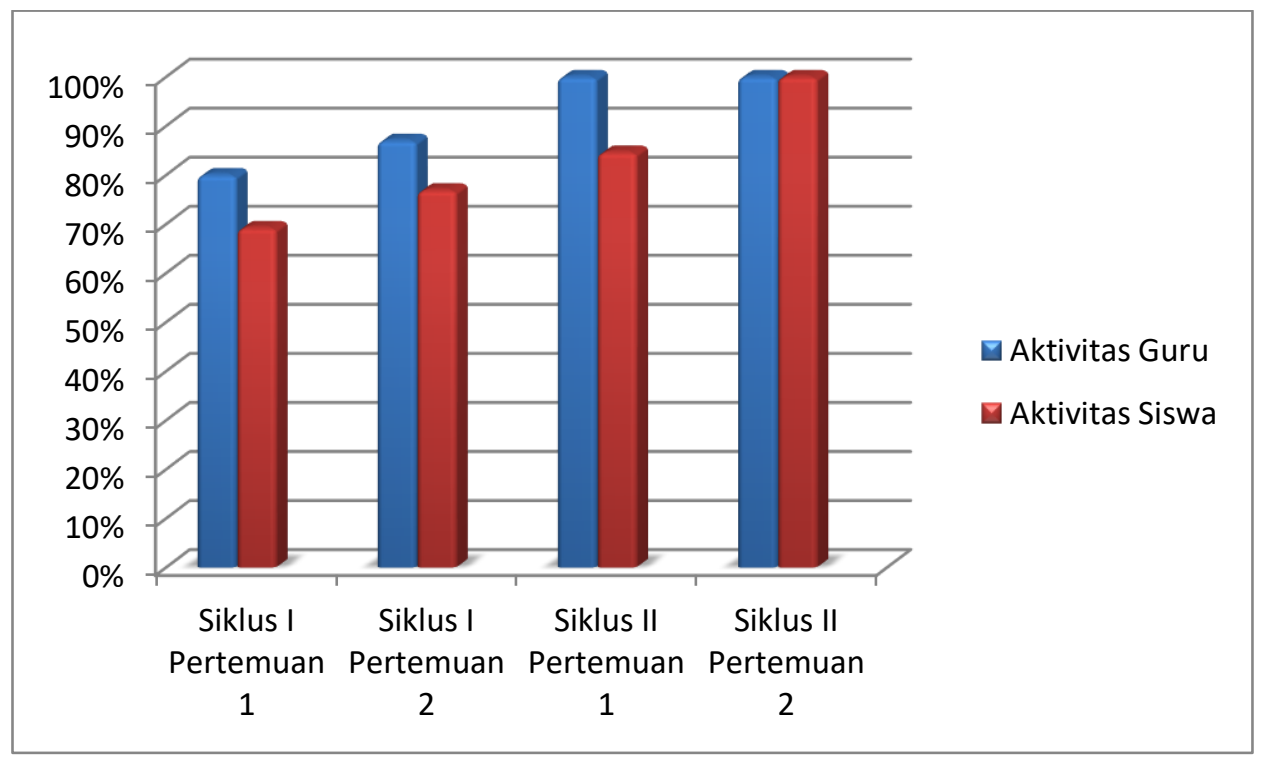

Gambar 1.

Aktivitas siswa pada siklus I sebesar 73\% dengan predikat cukup. Pada siklus I masih terdapat hal-hal yang perlu diperbaiki diantaranya, terdapat siswa yang belum dapat membuat 
catatan kecil, terdapat siswa yang pasif dalam kegiatan diskusi kelompok, dan siswa masih kesulitan dalam membuat kesimpulan. Berdasarkan hal tersebut, upaya guru untuk meningkatkan aktivitas siswa dengan cara memberikan bimbingan dan pengawasan secara menyeluruh. Hal itu terbukti pada siklus II persentase aktivitas siswa meningkat sebesar $92,3 \%$ dengan predikat sangat baik.

Hasil belajar siswa menerapkan model TTW dengan penguatan karakter demokratis materi menulis surat undangan pada siswa kelas V SD sebagai berikut.

Tabel 1.

\begin{tabular}{|c|c|c|c|c|c|c|}
\hline \multirow[b]{2}{*}{ No. } & \multirow[b]{2}{*}{ Hasil Belajar } & \multirow{2}{*}{$\begin{array}{l}\text { Pra- } \\
\text { tindakan }\end{array}$} & \multicolumn{2}{|c|}{ Siklus I } & \multicolumn{2}{|c|}{ Siklus II } \\
\hline & & & Pertemuan 1 & Pertemuan 2 & Pertemuan 1 & Pertemuan 2 \\
\hline \multirow[t]{7}{*}{1.} & Sikap & & & & & \\
\hline & Tanggung Jawab & & & & & \\
\hline & Persentase & - & $93,9 \%$ & $96,9 \%$ & $75,7 \%$ & $87,8 \%$ \\
\hline & Kriteria & - & Sangat Baik & Sangat Baik & Cukup & Baik \\
\hline & Demokratis & & & & & \\
\hline & Persentase & - & $80,8 \%$ & $84,4 \%$ & $93,9 \%$ & $100 \%$ \\
\hline & Kriteria & - & Baik & Baik & Sangat Baik & Sangat Baik \\
\hline \multirow[t]{6}{*}{2.} & Pengetahuan & & & & & \\
\hline & Rata-rata & 61 & 63,9 & 72,12 & 74,7 & 81,5 \\
\hline & Kriteria & & Kurang & Cukup & Cukup & Baik \\
\hline & & Kurang & & & & \\
\hline & Persentase KBK & $42 \%$ & $58 \%$ & $63,6 \%$ & $75,7 \%$ & $84,8 \%$ \\
\hline & Kriteria & $\begin{array}{l}\text { Sangat } \\
\text { Kurang }\end{array}$ & Sangat Kurang & Kurang & Cukup & Baik \\
\hline \multirow[t]{4}{*}{3.} & Keterampilan & & & & & \\
\hline & Menulis Surat Unc & & & & & \\
\hline & Persentase & - & $58 \%$ & 63,6\% & $81,8 \%$ & $90,9 \%$ \\
\hline & Kriteria & - & $\begin{array}{l}\text { Sangat } \\
\text { Kurang }\end{array}$ & Kurang & Baik & Sangat Baik \\
\hline
\end{tabular}

Berdasarkan tabel diatas dapat diketahui bahwa hasil belajar siswa mengalami peningkatan dari siklus I sampai II. Data tersebut menunjukkan bahwa implementasi model TTW dapat meningkatkan hasil belajar siswa yang meliputi aspek sikap, pengetahuan dan keterampilan.

\subsection{Pembahasan}

Berdasarkan temuan penelitian, diperoleh informasi bahwa penerapan model TTW dengan penguatan karakter demokratis pada materi menulis surat undangan dilaksanakan dua siklus yaitu siklus I dan siklus II. Jumlah keseluruhan aktivitas yang dilaksanakan oleh guru dan siswa pada siklus I pertemuan pertama yaitu 12 aktivitas, sedangkan siswa 9 aktivitas. Pada pertemuan kedua aktivitas guru yaitu 13 aktivitas, siswa 10 aktivitas. Hasil penelitian mulai dari tahap awal, siklus I, dan siklus II siswa kelas V SDN Kepanjenkidul 1 Kota Blitar mengalami peningkatan pada aktivitas guru dan siswa. Persentase aktivitas siswa pada siklus I sebesar 69,2\% dengan kriteria kurang juga meningkat pada siklus II menjadi 100\% dengan 
kriteria sangat baik. Hal ini menunjukan bahwa model TTW telah dilaksanakan dengan sangat baik oleh guru dan siswa.

Siklus I pertemuan pertama, ada 3 aktivitas yang belum dilaksanakan guru yaitu belum memberi arahan untuk mendiskusikan catatan kecil, menginformasikan untuk menulis hasil diskusi secara individu, dan mengkondisikan kelas saat kegiatan persentasi. Menurut Shoimin (2014) tahap talk yang berisi kegiatan siswa dalam berdiskusi dengan kelompoknya dan saling menyampaikan pendapatnya mengenai solusi yang ditawarkan dalam permasalahan tersebut, dan tahap write yang berisi kegiatan siswa dalam menuliskan hasil diskusi secara individu. Sesuai yang diadaptasi pada pendapat Shoimin pada langkah tersebut siswa harus dibimbing pada setiap tahapan TTW. Bedasarkan penjelasan tersebut, dapat diketahui bahwa guru masih belum melaksanakan pembelajaran sesuai dengan langkah-langkah model TTW.

Upaya perbaikan yang dilakukan pada siklus II yaitu guru harus mempelajari langkahlangkah model TTW, guru harus mengkondisikan kelas dengan baik, alokasi waktu dalam setiap kegiatan perlu diperhatikan, dan guru harus memberikan bimbingan kepada siswa. Berdasarkan hasil observasi dan analisis upaya yang dilaksanakan difokuskan pada pelaksanaan proses pembelajaran. Hal yang harus dipertahankan pada siklus II yaitu guru melaksanakan pembelajaran sesuai dengan langkah-langkah yang telah direncanakan dan memberikan penjelasan kepada siswa mengenai sikap demokratis dan tanggung jawab dalam kegiatan diskusi.

Pembelajaran pada siklus II guru telah sesuai dengan RPP yang telah direncanakan menggunakan model TTW dan didasarkan pada refleksi siklus I. Aktivitas guru pada siklus II mengalami peningkatan persentase keberhasilan yaitu 100\%. Hal tersebut terjadi karena diberikan perbaikan sesuai dengan kekurangan yang ada pada siklus I yaitu pada tahap pelaksanaan aspek talk, write dan penyampaian kesimpulan. Perbaikan tersebut diberikan oleh guru dengan cara membimbing dan memberikan instruksi pada siswa untuk menyampaikan pendapatnya mengenai catatan kecil tentang teks surat undangan resmi yang telah dibagikan. Selanjutnya, guru memberikan pengawasan serta berkeliling kelas untuk memastikan apakah terdapat kelompok yang mengalami kesulitan dalam menuliskan hasil diskusinya terkait surat undangan resmi. Ketika terdapat kelompok yang kesulitan dalam menuliskan hasil, guru memberikan pengarahan secara detail pada kelompok tersebut agar pembelajarannya dapat maksimal. Sedangkan pada aspek penyampaian kesimpulan guru sebelumnya telah mengkondisikan kelas secara tertib, sehingga pada tahap refleksi tersebut siswa dapat mengemukakan pendapatnya mengenai materi yang telah dipelajari secara tertib. Hal tersebut memudahkan guru untuk menunjuk para siswa secara bergantian untuk menggali pemahaman siswa terkait materi yang telah diajarkan.

Pembelajaran pada siklus I dan II dilaksanakan sesuai dengan langkah-langkah model TTW yang telah dikemukakan oleh Shoimin (2014) yang meliputi (1) tahap think yang berisi kegiatan membaca teks LKPD dan menuliskan permasalahan yang ada di dalam teks pada catatan kecil, (2) tahap talk yang berisi kegiatan siswa dalam berdiskusi dengan kelompoknya dan saling menyampaikan pendapatnya mengenai solusi yang ditawarkan dalam permasalahan tersebut, (3) tahap write yang berisi kegiatan siswa dalam menuliskan hasil diskusi secara individu. Permasalahan tersebut terkait dengan materi penulisan surat undangan resmi. Adapun seluruh tahapan tersebut, diakhiri oleh kegiatan penyimpulan 
pembelajaran atau kegiatan refleksi yang bertujuaan untuk menelaah materi-materi yang telah dipelajari bersama.

Pembelajaran dengan menggunakan model TTW pada siklus I dan II menimbulkan antusiasme siswa sehingga meningkatkan minat siswa dalam mengikuti pembelajaran. Melalui model TTW siswa lebih aktif dalam pembelajaran dibandingkan pada saat pratindakan. Penerapan model TTW dapat meningkatkan aktivitas siswa. Hal tersebut dibuktikan dari ratarata persentase aktivitas siswa pada siklus I sebesar 69,2\% dengan kriteria kurang.

Persentase $69,2 \%$ menunjukkan bahwa masih ada empat aktivitas yang belum muncul pada pertemua 1. Aktivitas yang belum muncul yaitu siswa belum yaitu siswa belum bisa membuat catatan kecil, dalam berdiskusi siswa masih pasif dan belum percaya diri menyampaikan pendapat, siswa belum mempresentasikan hasil diskusi di depan kelas dan memberi tanggapan pada kegiatan presentasi. Pelaksanaan pada pertemuan 2 aktivitas siswa mengalami peningkatan yaitu ada 10 aktivitas yang telah dilaksaknakan dari total keseluruhan 13 aktivitas dengan persentase 76,9\%. Hal ini terjadi karena adanya upaya perbaikan yang dilakukan oleh guru melalui pemberian bimbingan dan motivasi.

Bimbingan dan motivasi dari guru meningkatkan persentase aktivitas siswa pada siklus II pertemuan 1 sebesar 84,6\%. Hal ini menunjukkan masih ada 2 aktivitas yang belum muncul yaitu terdapat 1-2 siswa masih pasif dalam kegiatan diskusi secara berkelompok, siswa masih kesulitan dalam membuat kesimpulan. Pernyataan tersebut dibuktikan ada 6 siswa yang memerlukan bimbingan dalam membuat kesimpulan. Pelaksanaan pada pertemuan 2 aktivitas siswa mengalami peningkatan menjadi $100 \%$ dengan kriteria sangat baik. Berdasarkan temuan yang diperoleh dari hasil observasi aktivitas guru dan aktivitas siswa maka dapat disimpulkan bahwa penerapan model TTW pada materi menulis surat undangan dapat meningkatkan aktivitas siswa kelas V di SDN Kepanjenkidul 1 Kota Blitar.

Berdasarkan paparan data yang telah diuraikan, hasil belajar siswa aspek sikap, pengetahuan dan keterampilan mengalami peningkatan dari tahap pratindakan hingga siklus II. Tes tahap awal penelitian hanya terbatas pada dimensi pengetahuan dengan nilai rata-rata 61. Jumlah siswa kelas V SDN Kepanjenkidul 1 Kota Blitar 33 siswa. Terdapat 14 siswa yang tuntas belajar, dan 19 siswa yang tidak tuntas belajar. Persentase ketuntasan belajar klasikal pra tindakan yaitu $42 \%$ dengan kriteria kurang dan belum mencapai standar ketuntasan belajar klasikal sebesar $80 \%$. Persentase yang dicapai siswa masih sangat rendah, sehingga perlu dilakukan perbaikan pelaksanaan pembelajaran pada muatan bahasa Indonesia materi surat undangan melalui model TTW pada siklus I dan siklus II.

Penilaian sikap atau karakter pada penelitian dilakukan dengan memberikan penilaian pada butir sikap yang muncul dan dilakukan oleh siswa. Pada penelitian ini, terdapat hasil temuan yang muncul bahwa ketika kegiatan belajar mengajar, siswa sudah dapat berdiskusi, saling menghargai pendapat teman dan percaya diri dalam mengemukakan pendapatnya. Hal tersebut sesuai dengan salah satu nilai karakter pada kurikulum 2013 yaitu toleransi (Depdiknas, 2010). Selain hal tersebut, dalam pembentukan kelompok juga terdapat nilai pendidikan karakter yaitu rasa demokratis dalam menghargai hasil jawaban anggota kelompoknya (Depdiknas, 2010).

Siswa juga diajarkan cara berbicara, mendengarkan, memberikan tanggapan, serta memberikan kesempatan yang sama pada setiap anggota kelompoknya untuk mengeluarkan 
argumennya. Paparan tersebut diperkuat oleh Azzet (2011) bahwa untuk menumbuhkan karakter domokratis membutuhkan sikap percaya diri, kerjasama, berempati, dan berkomunikasi. Siswa mempresentasikan hasil diskusi di depan kelas dan kelompok lain menanggapi kelompok yang presentasi. Pada tahapan ini, siswa harus dibiasakan untuk melatih karakter demokratisnya pada aspek komunikasi. Merujuk pada pendapat Azzet (2011) bahwa komunikasi merupakan sikap dasar dalam karakter demokratis. Hal tersebut dikarenakan sepandai apapun siswa dalam pelajaran, jika tidak dapat mendengarkan dan menghargai pendapat orang lain maka penumbuhan karakter tersebut tidak membuahkan hasil. Sikap demokratis pada pada kelas V mengalami peningkatan dari kriteria baik menjadi sangat baik pada siklus II.

Data pada siklus I menunjukkan bahwa sikap demokratis telah meningkat dari 80,8\% dengan kriteria baik pada pertemuan 1 menuju84,4\% dengan kriteria baik pada pertemuan 2 . Ada 27 siswa yang menunjukkan sikap demokratis dengan saling menghargai teman pada pertemuan 1. Selain itu, 15 siswa menunjukkan sikap demokratis dengan berani mengemukakan pendapat, 13 siswa menunjukkan sikap demokratis dengan percaya diri dan tidak bergantung terhadap orang lain. Pertemuan 2 Ada 28 siswa yang menunjukkan sikap demokratis dengan saling menghargai teman. Selain itu, 18 siswa menunjukkan sikap demokratis dengan berani mengemukakan pendapat, 16 siswa menunjukkan sikap demokratis dengan percaya diri dan tidak bergantung terhadap orang lain.

Sikap demokratis pada siklus II meningkat hingga 100\% dengan kriteria sangat baik. Sikap demokratis pada pertemuan 1 yaitu 93,9\% dengan kriteria sangat baik. Terdapat 31 siswa yang menunjukkan sikap demokratis dengan saling menghargai teman. Kemudian 19 siswa menunjukkan sikap demokratis dengan berani mengemukakan pendapat, dan 16 siswa menunjukkan sikap demokratis dengan percaya diri dan tidak bergantung terhadap orang lain. Pada pertemuan 2 meningkat hingga 100\%. Ada 33 siswa yang menunjukkan sikap demokratis dengan saling menghargai teman. Kemudian 25 siswa menunjukkan sikap demokratis dengan berani mengemukakan pendapat, dan 18 siswa menunjukkan sikap demokratis dengan percaya diri dan tidak bergantung terhadap orang lain.

Sikap demokratis ditumbuhkan beriringan dengan sikap tanggung jawab karena di dalam nilai dasar sikap demokratis, terdapat sikap tanggung jawab. Hal ini di perkuat oleh pendapat (Setiawan, 2014) bahwa nilai dasar dari nilai demokratis yaitu toleransi, percaya diri, mandiri, menghargai, bertanggung jawab, kerjasama, dan menghargai perbedaan. Sikap tanggung jawab pada pada kelas V mengalami peningkatan hingga siklus II.

Data pada siklus I menunjukkan bahwa seluruh siswa telah memiliki sikap tanggung jawab. Persentase sikap tanggung jawab pada pertemuan 1 sebesar $93,9 \%$ dan pertemuan 2 yaitu $96,9 \%$ dengan kriteria sangat baik. Hal ini dikarenakan 31 siswa memiliki indikator melaksanakan tugas individu dengan baik. Selain menunjukkan pada indikator tersebut, ada 11 siswa yang menunjukkan sikap tanggung jawabnya melalui menerima resiko dari tindakan yang dilakukan, dan 10 siswa menunjukkan sikap tanggung jawab dengan mengakui kesalahan dan tidak melempar kesalahan kepada teman. Pada pertemuan 2, ada 32 siswa memiliki indikator melaksanakan tugas individu dengan baik, 16 siswa yang menunjukkan sikap tanggung jawabnya melalui menerima resiko dari tindakan yang dilakukan, dan 17 siswa menunjukkan sikap tanggung jawab dengan mengakui kesalahan dan tidak melempar kesalahan kepada teman. 
Data sikap tanggung jawab pada siklus II pertemuan 1 dengan persentase sebesar 75,7\% dengan kriteria cukup. Meningkat pada pertemuan 2 dengan persentase sebesar 87,8\% dengan kriteria baik. Ada 25 siswa menunjukkan sikap tanggung jawab dengan melaksanakan tugas individu dengan baik pada pertemuan 1. Kemudian 15 siswa yang menunjukkan sikap tanggung jawabnya melalui menerima resiko dari tindakan yang dilakukan, dan 12 siswa menunjukkan sikap tanggung jawab dengan mengakui kesalahan dan tidak melempar kesalahan kepada teman. Pada pertemuan 2, ada 29 siswa memiliki indikator melaksanakan tugas individu dengan baik, 15 siswa yang menunjukkan sikap tanggung jawabnya melalui menerima resiko dari tindakan yang dilakukan, dan 12 siswa menunjukkan sikap tanggung jawab dengan mengakui kesalahan dan tidak melempar kesalahan kepada teman.

Aspek pengetahuan pada siklus I pembelajaran 1 menunjukan bahwa nilai rata-rata kelas V yaitu 63,9 dengan persentase 58\%. Nilai pengetahuan siswa meningkat pada siklus I pertemuan II dengan rata-rata kelas yaitu 72,12 atau persentase ketuntasan belajar siswa $63,6 \%$. Secara umum penilaian aspek pengetahuan pada siklus I dapat dikatakan belum tuntas. Hal ini dikarenakan persentase ketuntasan belajar siswa belum mencapai $80 \%$. Upaya perbaikan yang dilakukan guru untu tindakan siklus II yaitu menggunakan model TTW disertai pemberian bimbingan secara menyeluruh.

Selanjutnya upaya perbaikan pada aspek pengetahuan pada siklus II pembelajaran 1 menunjukan bahwa nilai rata-rata kelas $V$ meningkat menjadi 74,7 dengan persentase $75,7 \%$. Persentase tersebut menunjukkan bahwa pada aspek pengetahuan dengan ketuntasan belajar klasikal kriteria cukup. Nilai pengetahuan siswa meningkat pada siklus II pertemuan 2 dengan rata-rata kelas yaitu 81,5 atau persentase ketuntasan belajar siswa 84,4\%. Secara umum penilaian aspek pengetahuan pada siklus II dapat dikatakan tuntas. Hal ini dikarenakan persentase ketuntasan belajar klasikal pada siklus II telah melampaui $80 \%$ dengan kriteria sangat baik.

Pada siklus I jumlah siswa yang tuntas atau mendapatkan nilai optimum masih dalam kategori sangat kurang. Nilai optimum diperoleh apabila siswa memenuhi 2 indikator penilaian. Persentase ketuntasan siswa telah meningkat dari 58\% dengan kriteria sangat kurang pada pertemuan 1 . Pada pertemuan 2 meningkat namun masih pada kriteria kurang. Aspek keterampilan pada siklus I pembelajaran 1, 18 siswa yang mampu mendapatkan nilai optimum. Kemudian jumlah siswa meningkat pada siklus I pembelajaran 2 yaitu ada 23 siswa yang mendapatkan nilai optimum dengan persentase $63,6 \%$. Secara umum penilaian aspek keterampilan pada siklus I dapat dikatakan belum tuntas, karena secara klasikal persentase keberhasilan belum mencapai standar yaitu $80 \%$. Hal ini menujukkan bahwa perlu adanya bimbingan dan usaha peningkatan pada siklus II.

Aspek keterampilan pada siklus II pembelajaran 1 siswa yang mampu mendapatkan nilai optimum meningkat menjadi 27 siswa atau 81,8\% dengan kriteria baik. Kemudian, nilai keterampilan siswa meningkat pada siklus II pembelajaran 2 yaitu 30 siswa yang mendapatkan nilai optimum dengan persentase 90,9\%. Secara umum penilaian aspek keterampilan pada siklus II dapat dikatakan tuntas, karena secara persentase siswa yang memiliki nilai optimum telah mencapai $80 \%$ dengan kriteria baik. Hal ini sesuai dengan pendapat Sudjana (2009) bahwa suatu kelas secara klasikal dapat dikatakan tuntas jika dalam suatu kelas ketuntasan belajar siswa lebih atau sama dengan $80 \%$. 
Uraian pembahasan menyatakan bahwa terjadi peningkatan hasil belajar siswa pada dimesi sikap, pengetahuan, dan keterampilan. Penerapan model TTW dengan penguatan karakter demokratis yang diterapkan dengan benar, berdampak baik pada hasil belajar siswa. Dampak yang ditunjukkan yaitu meningkatnya aktivitas guru dan siswa dari kriteria baik menjadi sangat baik. Selain itu pada juga terjadi peningkatan pada rata-rata pengetahuan siswa dari kriteria sangat kurang menjadi baik. Pada penilaian sikap kerjasama juga terjadi peningkatan dari kriteria baik menjadi sangat baik. Pencapain terbaik pada penelitian ini yaitu meningkatkan sikap demokratis, persentase KK pada aspek pengetahuan, dan keterampilan menulis surat undangan dari sangat kurang menjadi sangat baik.

\section{Simpulan}

Pelaksanaan pembelajaran menulis surat undangan resmi melalui model Think Talk Write (TTW) di kelas V SDN Kepanjenkidul 1 Kota Blitar dilaksanakan dengan baik sesuai langkah-langkah dalam model TTW. Hal ini dapat dapat dilihat dari penerapan model TTW dapat meningkatkan aktivitas guru dan siswa dalam pembelajaran menulis surat undangan resmi. Persentase aktivitas guru pada siklus I sebesar 83\% dengan predikat ketuntasan baik dan meningkat pada siklus II mencapai $100 \%$ dengan predikat ketuntasan sangat baik. Persentase aktivitas siswa dari siklus I dan II juga meningkat, aktivitas siswa siklus I sebesar 73\% dengan predikat ketuntasan cukup dan meningkat pada siklus II mencapai 92\% dengan predikat ketuntasan sangat baik.

Penerapan model TTW dalam pembelajaran dapat meningkatkan keterampilan menulis surat undangan resmi pada siswa kelas V, setelah menerapkan model TTW pada pembelajaran, hasil persentase ketuntasan klasikal mengalami peningkatan pada siklus I yaitu sebesar $62 \%$ dan meningkat pada siklus II yakni $86 \%$. Hal ini menunjukkan bahwa terjadi peningkatan hasil belajar siswa sebelum dan sesudah diberi tindakan.

Berdasarkan penelitian yang telah dilaksanakan, maka peneliti memberikan saran dalam menerapkan model TTW pada tahap talk hendaknya guru memberikan arahan saat berdiskusi dan membimbing siswa yang mengalami kesulitan, pada tahap write setiap memasuki tahap selanjutnya agar siswa tertib dan mengkondisikan kelas agar kondusif. Selain itu, disarankan untuk memotivasi siswa agar siswa lebih aktif dalam kegiatan diskusi, agar pada tahap persentasi siswa lebih aktif dalam memberi masukan satu sama lain, selain itu, disarankan untuk membimbing siswa di setiap tahap agar tujuan pembelajaran tercapai secara optimal.

\section{Daftar Rujukan}

Azzet, A. M. (2011). Urgensi Pendidikan Karakter Indonesia Revitalisasi Pendidikan Karakter terhadap Keberhasilan Belajar dan Kemajuan Bangsa. Yogyakarta: Ar-Ruzz Media.

Haryati, S. (2017). Pendidikan Karakter dalam Kurikulum 2013. Tersedia secara online di: http://lib. untidar. ac. id/wp-content/uploads. Diakses tanggal 16 Desember 2019.

Kemdiknas. (2010). Pedoman sekolah: pengembangan pendidikan budaya dan karakter bangsa. Jakarta: Kemdiknas.

Mudiono, A. (2010). Pengembangan Bahan Pembelajaran Bahasa Indonesia Sekolah Dasar. Malang: Universitas Negeri Malang.

Nurjamal \& Sumirat, (2010). Penuntun perkuliahan Bahasa Indonesa. Bandung: Alfabeta.

Shoimin, A. (2014). 68 Model Pembelajaran Inovatif dalam Kurikulum 2013. Yogyakarta: Ar-Ruzz Media.

Susanto, A. (2016). Teori Belajar dan Pembelajaran di Sekolah Dasar. Jakarta: Prenamedia Group. 
Jurnal Pembelajaran, Bimbingan, dan Pengelolaan Pendidikan, 1(2), 2021, 130-140

Soedjito. (2018). Surat Menyurat Resmi Bahasa Indonesia. Jakarta: Prestasi Pustaka Raya. 